ENTREPRENEURSHIP AND SUSTAINABILITY ISSUES

ISSN 2345-0282 (online) http://jssidoi.org/jesi/ 2021 Volume 9 Number 1 (September)

http://doi.org/10.9770/jesi.2021.9.1(36)

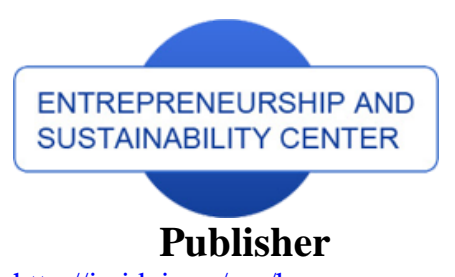

enterprise europe network

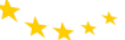

Business Support on Your Doorstep
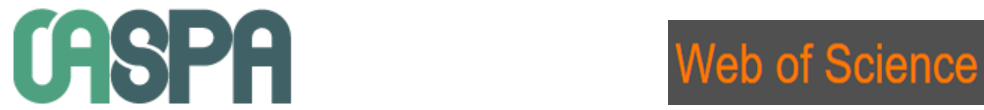

http://jssidoi.org/esc/home

is Clarivate

Analytics

\title{
MOBILITY IN THE CONTEXT OF ENTREPRENEURIAL POTENTIAL OF STUDENTS UNDER THE CONDITIONS OF THE COVID-19 PANDEMIC (LATVIA, GEORGIA)*
}

\author{
Vladimir Menshikov $^{1}$, Givi Bedianashvili ${ }^{2}$, Oksana Ruza ${ }^{3}$, Irena Kokina ${ }^{4}$ \\ ${ }^{1,3}$ Daugavpils University, Parades Str. 1, Daugavpils, LV-5401, Latvia \\ ${ }^{2}$ European University, Guramishvili Avenue 76, Tbilisi, Georgia \\ ${ }^{2}$ Ivane Javakhishvili Tbilisi State University, University Str.2, Tbilisi, 1086, Georgia \\ ${ }^{4}$ Daugavpils University, Vienibas Str. 13, Daugavpils, LV-5401, Latvia \\ E-mails: ${ }^{1}$ vladimirs.mensikovs@du.lv, ${ }^{2}$ g.bedianashvili@eu.edu.ge, ${ }^{3}$ oksana.ruza@du.lv, ${ }^{4}$ irena.kokina@du.lv
}

Received 15 June 2021; accepted 20 August 2021; published 30 September 2021

\begin{abstract}
The aim of the study is to assess the role of the university environment of higher education institutions in Latvia in the formation and promotion of the entrepreneurial potential of students under the conditions of the COVID-19 pandemic, paying special attention to the impact of the protracted epidemic crisis on entrepreneurial mobility. In the scientific literature, various systems of mobility are predominantly positively assessed in terms of increasing labour activity, given the increasing availability of distance employment. At the same time, distance employment also has some negative aspects, mainly reflected in the issues of social trust. In our case, the research problem was to elucidate the impact of the crisis in the life of universities, primarily the massive transition to distance learning, on the state of the entrepreneurial potential of students, especially in terms of their entrepreneurial mobility. For this purpose, exploratory research was carried out at the universities of Latvia (Daugavpils University) and Georgia (Ivane Javakhishvili Tbilisi State University and European University). The results of the sociological survey show that the massive transition to distance learning, the expansion the use of information and communication technology by students, is still only to a small extent continued in increasing the entrepreneurial potential, expanding entrepreneurial mobility. Moreover, the crisis situation related to the COVID-19 pandemic even more constrains students to implement their ideas in the field of personal business due to a one-sided attitude to risk as an unequivocally negative factor in the field of entrepreneurship. On the basis of the empirical data obtained, recommendations were made to the administration of universities and the leaders of public associations dealing with the promotion of entrepreneurial activity of students on the basis of more effective ways to increase their entrepreneurial mobility. The methods used by the authors include axiomatic analysis and synthesis, monographic, sociological survey, statistical analysis of quantitative data from a questionnaire survey.
\end{abstract}

Keywords: potential; entrepreneurial potential; mobility, students, Latvia, Georgia.

Reference to this paper should be made as follows: Menshikov, V., Bedianashvili, G., Kokina, I., Ruza, O. (2021). Mobility in the context of entrepreneurial potential of students under the conditions of the COVID-19 pandemic (Latvia, Georgia). Entrepreneurship and Sustainability Issues, 9(1), 574-589. http://doi.org/10.9770/jesi.2021.9.1(36)

JEL Classifications: L26, J24, M13, I21

\footnotetext{
* The article has been elaborated within research project No.14-95/2021/17 of Daugavpils University "The potential of student entrepreneurship and its promotion in Latvia, Ukraine and Georgia".
} 


\section{Introduction}

The COVID-19 pandemic has significantly exacerbated the entire range of problems of the preservation and sustainable development of mankind, even those that were not previously so urgent and critical. UN SecretaryGeneral Antonio Guterres argues that the COVID-19 crisis is an opportunity to rethink the issue of human mobility (Guterrish 2021). The United Nations Economic Commission for Europe (UNECE) has recently released the Guidelines on Sustainable Urban Mobility and Spatial Planning to help stimulate urban regeneration. "Mobility is a critical issue for the 3.5 billion people who today live in cities around the world for their livelihoods, services and social life", the UNECE document says. This is especially important in the highly urbanized UNECE region, where over $75 \%$ of the population of Europe, $80 \%$ of North America and about $50 \%$ of Central Asia are concentrated in urban areas" (United 2020). Along with this, the pandemic, with all its grave consequences, is a catalyst for innovative solutions in the field of online education, telecommunication solutions, IT solutions, and makes us look from a different angle at the problems that arise in the event of a job loss or other opportunities. Among the industries most affected by the pandemic and the associated closure of state borders, the most frequently mentioned are tourism, catering, shipping and international trade in general. International educational cooperation and, in particular, academic mobility as a victim of the coronavirus is mentioned much less often in domestic and foreign media and high-level political statements. Empirical studies have recently paid great attention to the role of environmental factors in explaining regional differences in entrepreneurial activity (Linan et al. 2011). So far, there are few scientific and political and economic publications on the impact of the pandemic on student entrepreneurial activity, on its mobility in this area.

\section{Mobility in the analysis of entrepreneurial potential (the international aspect of research)}

The general interest of researchers in the issue of mobility has increased significantly in recent years. More often than not, the concept of "mobility" is used to describe innovation and novelty both in the world of technology and in the system of social relations. Let us analyse, for example, the reflection of mobility issues in the acknowledged Scopus database.

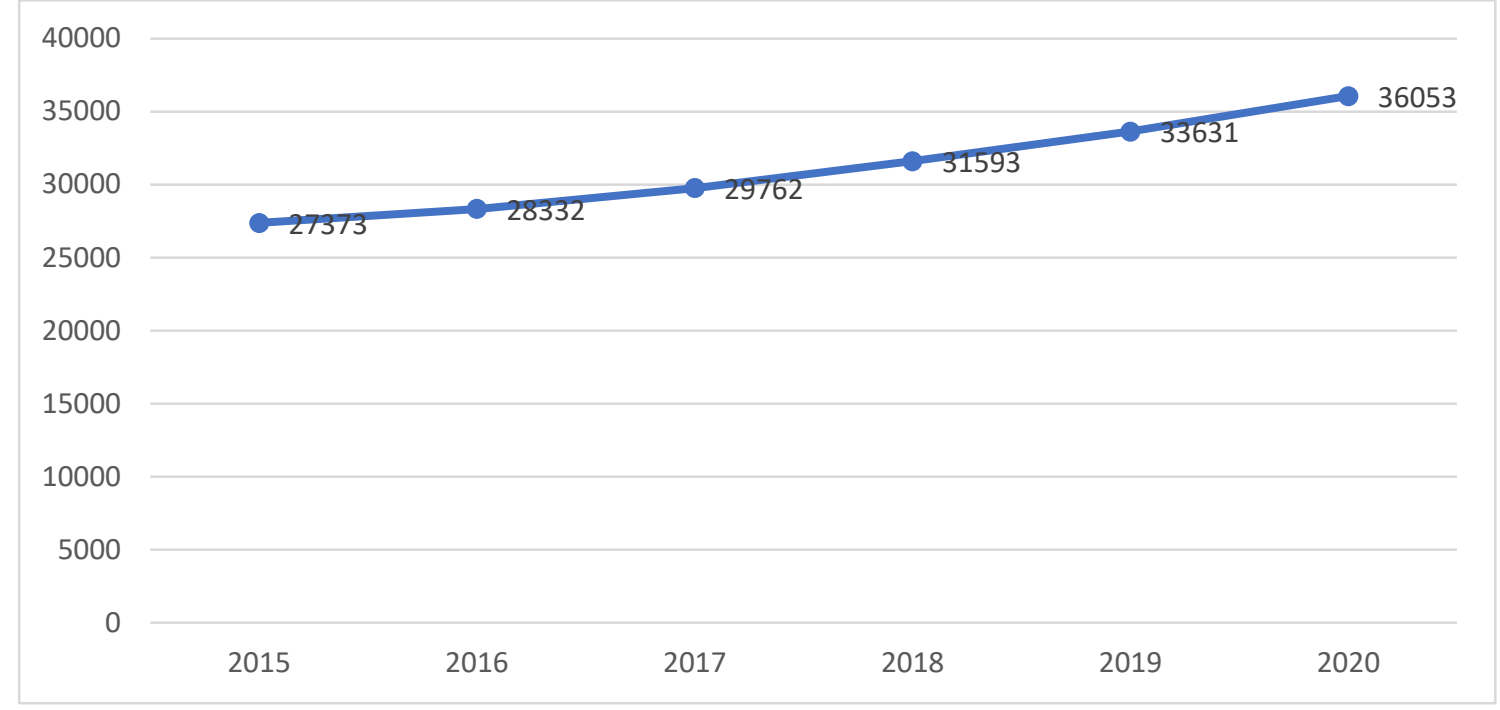

Figure 1. Number of documents per year containing the words "mobility" in the title, abstract or keywords in the Scopus database from 2015 to 2020

Source: elaborated by the authors based on SCOPUS1 database 
The results shown in Fig. 1 confirm the high interest of scientists from various branches of science in the topic "mobility". Publications on the topic "mobility" were indexed especially rapidly in the Scopus database in 2020, when the number of such publications increased compared to 2015 and reached 36,053. Most of the publications are related to the natural sciences and technical sciences, at the same time, $7.7 \%$ of the total are represented by social sciences.

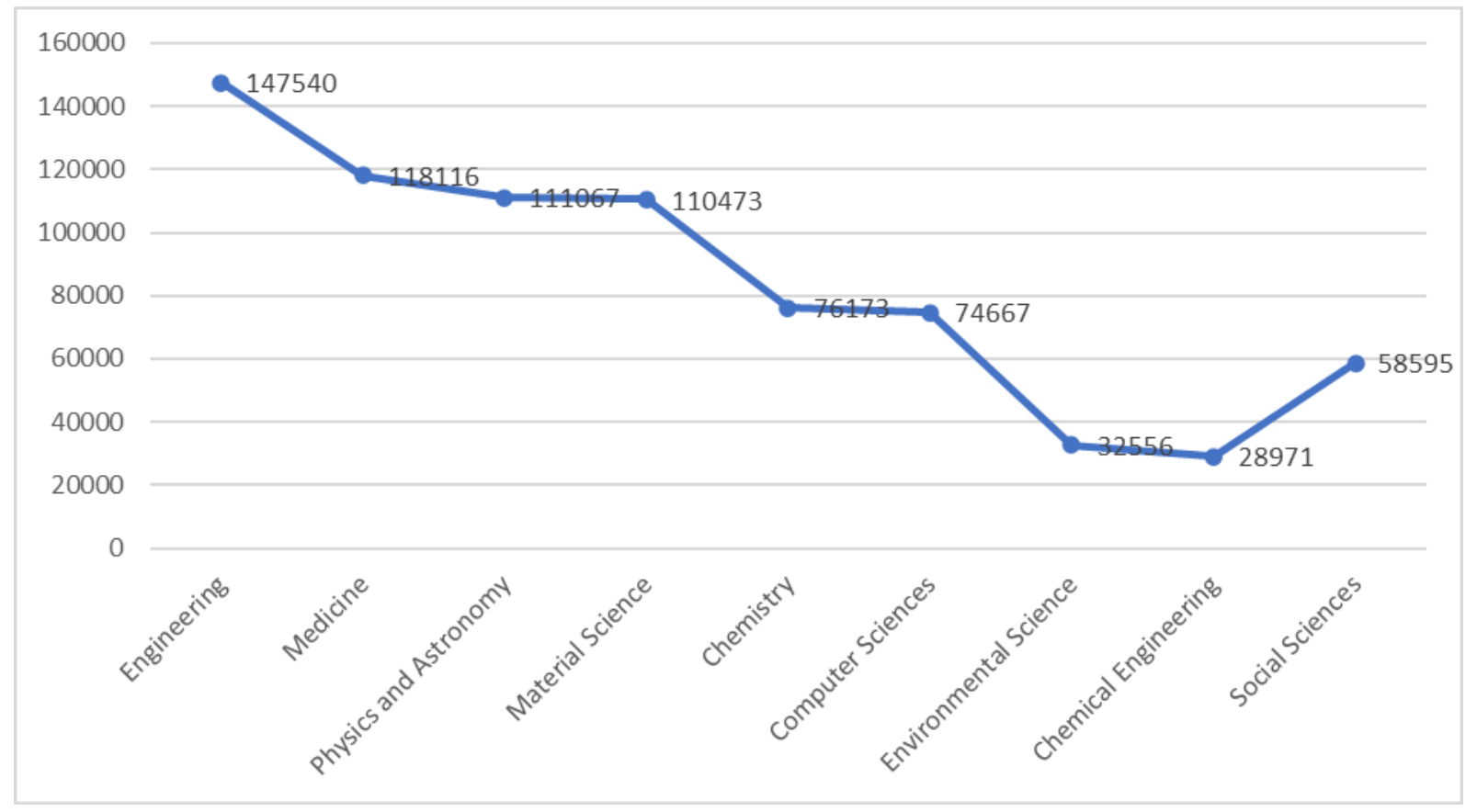

Figure 2. Number of documents by branch of science that contain the words "mobility" in the title, abstract or keywords in the Scopus database from 2015 to 2021

Source: elaborated by the authors based on SCOPUS2 database (SCOPUS 2021)

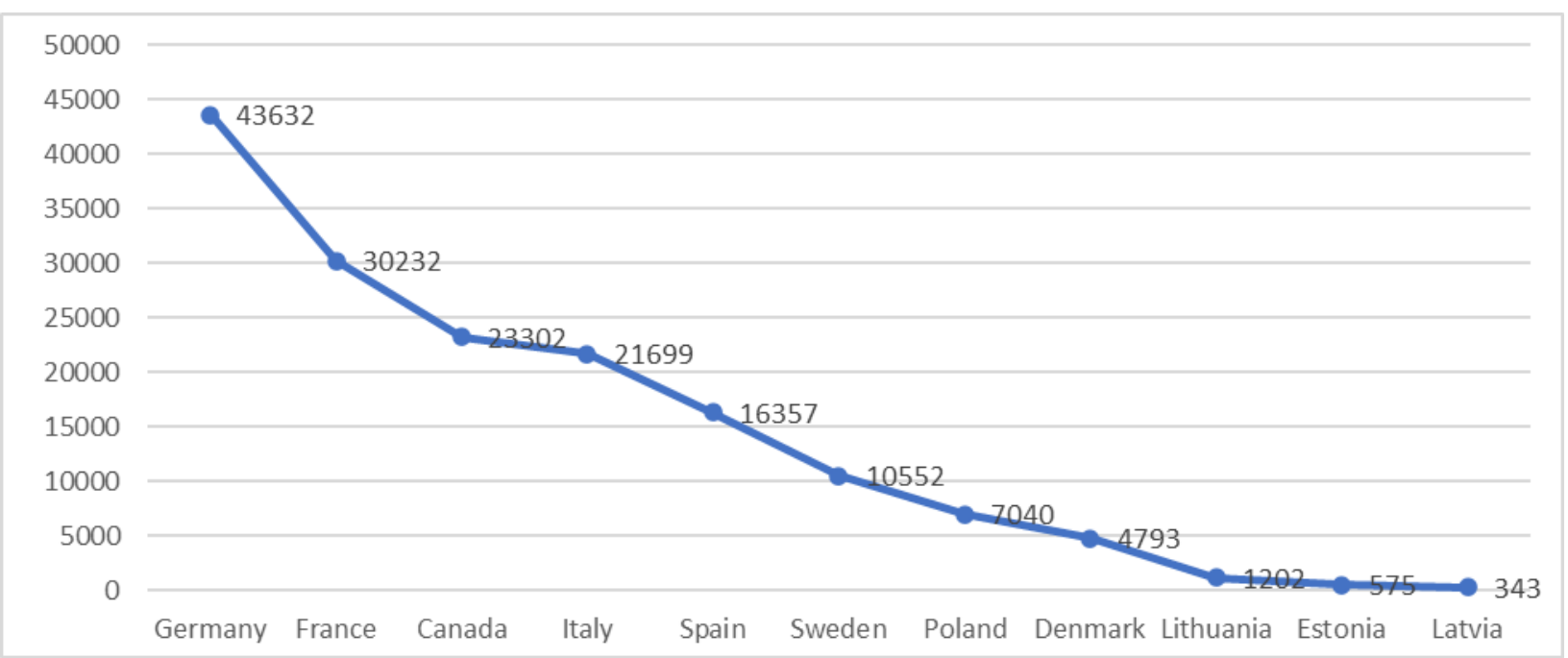

Figure 3. Number of documents by country that contain the words "mobility" in title, abstract or keywords in Scopus database from 2015 to 2021

Source: elaborated by the authors based on SCOPUS3 database (SCOPUS 2021) 


\section{ENTREPRENEURSHIP AND SUSTAINABILITY ISSUES}

ISSN 2345-0282 (online) http://jssidoi.org/jesi/

2021 Volume 9 Number 1 (September)

http://doi.org/10.9770/jesi.2021.9.1(36)

The article by Colin McFarlane, Professor of Urban Geography from Durham University (UK), published in 2012, has the largest number of citations (McFarlane 2012). This paper studies co-production of urban entrepreneurship by examining the work of civil society groups on creating models of mobile entrepreneurship in slums. While slums and slum activists have mainly been absent from reports on urban entrepreneurship, they are playing an increasingly important role in creating models of mobile entrepreneurship and in creating and evaluating certain forms of entrepreneurial subjectivity. Focusing on co-production of entrepreneurship requires attention both to the mobile models that constitute relationships between different groups, from states and donors to activists and residents, and to the local contexts and stories that shape and implement entrepreneurship in different ways. In conclusion, the article highlights three values for the study of urban entrepreneurship. Urban entrepreneurship, as the author states, is a far-reaching ideology (methodology) for urban governance, which is characterized by three central elements: competition between cities in order to attract more and more mobile sources of capital investment; the powerful influence of market ideologies on the trajectory and content of urban development; and secondary distributional policy that favours growth and wealth accumulation. As we may see, the author widely uses the concept of "mobility" - "mobility of business models", "mobile sources of capital investment", "mobility of urban policy", not paying much attention to either clarifying the essence of the concept itself or the possible content of its various aspects.

The article by Swedish sociologists Bienkowska D., Klofsten M. (Bienkowska \& Klofsten 2012) take the second place in terms of the frequency of citing of publications indexed in the Scopus database.

The object of research (postgraduate students) and especially the subject of research (mobility as network capital) allows the authors of this paper to more clearly define the key issues of the proposed topic of their own research. The activities of PhD students aimed at job creation are an important area of study that contributes to deepening our understanding of academic entrepreneurship. The article focuses on the participation of $\mathrm{PhD}$ students in network-building activities, defined as mobility and collaboration, as well as their own interest and the estimated degree of support for commercialization from different levels of the university hierarchy. The results of a largescale survey presented in the article (1126 PhD students at Linköping University, Sweden, $41 \%$ of respondents) show that the majority of $\mathrm{PhD}$ students cooperate with external organisations, although quite a few (one quarter) spent part of their Doctoral studies outside their home university. PhD students in all faculties are on average interested and in favour of commercialization. However, $\mathrm{PhD}$ students of the Faculty of Medical Sciences say they find it difficult to combine research and commercialization. In addition, the interest in the commercialization of research results is relatively low among those $\mathrm{PhD}$ students who apply for internships at other universities, which is indicative of experienced incompatibility between research and academic entrepreneurship.

When developing networks, human mobility is an effective mechanism and may even be considered necessary for the initial formation of a network, as it is a precondition for face-to-face meeting and interaction (Urry 2013; Urry 2002). Face-to-face communication is an important way to build trust between people through the investment, effort, money and time that emerge when people come together (Storper \& Anthony 2004).

Urry notes that "mobility in general is central to "uniting social networks" and "the connections that emerge from co-presence can generate relationships of trust that enhance both social and economic integration". Moreover, mobility automatically implies immersion in a different environment, which provides a multifaceted learning experience that cannot be achieved in any other way.

There is an increasing number of scientific articles, where the search results of representatives of various scientific disciplines using the concept of "mobility" are integrated. For example, Swedish entrepreneurship researchers Erik Landmark and Margda Waern point to eight aspects of the relationship between mobility and entrepreneurship: people mobility, knowledge mobility, mobility of ideas, mobility of opportunities, resource 


\section{ENTREPRENEURSHIP AND SUSTAINABILITY ISSUES}

ISSN 2345-0282 (online) http://jssidoi.org/jesi/

2021 Volume 9 Number 1 (September)

http://doi.org/10.9770/jesi.2021.9.1(36)

mobility, mobility of social relations/networks or social mobility, mobility of infrastructure and organisational mobility (Lundmark \& Waern 2008).

In addition to the important theory of strategic entrepreneurship, some researchers use the undeniably influential theory of resources and the theory of entrepreneurial behaviour in their scientific research. All three theories form the basis for the formulation of entrepreneurial mobility, which provides a better understanding of the activities of enterprises and is a factor helping entrepreneurs to go beyond their usual boundaries.

Researchers on the promotion of entrepreneurial potential propose to use more widely the concept of "entrepreneurial mobility", which integrates various manifestations of flexibility and adaptation to a rapidly changing business environment. It is noted that entrepreneurial mobility is a multidimensional construct. Which area an entrepreneur will find himself in depends on one's resources, competences, ability to seize opportunities, entrepreneurial behaviour and strategic entrepreneurship that help to understand the construction of mobile entrepreneurship (Bednarska 2019).

The emergence of entrepreneurial mobility is seen as a career without boundaries, aiming at transcending boundaries in the context of professional development. Thus, Zahra, Wright base their analytical model of entrepreneurial mobility on 4 contexts of possible movements in the business sphere:

1. temporal (enterprise life cycle),

2. institutional (public policy, legal system, norms, values),

3. social (social media) and

4. spatial (geographic space) (Zahra \&Wright 2011).

However, the proposed model practically does not emphasize the rapidly growing role of mobility in the virtual space.

The direction of mobile communication technologies and data transmission mobility is becoming an actively developing area in the world of modern information technologies. The development of data transmission technologies leads to the restructuring of the entire information industry and the integration of telecommunications, computer and television networks. The development of wireless mobile communication technologies changes the lifestyle of a person allowing him to be more and more mobile. The combination of these technologies provides mobile access to the resources of the Internet, which will ultimately change its world. Various mobile data services based on mobile Internet access technology provide subscribers with a wide range of online services:

- operations with securities,

- purchasing goods,

- banking operations;

- payments to accounts of various types,

- $\quad$ navigation and search for objects in the city and much more.

The main advantage of the mobile Internet for enterprise employees is freedom of movement with access to the information they need.

\section{Mobility of students in Latvia as the most important component of their entrepreneurial potential (theoretical and methodological aspect and some empirical indicators)}

Even before the Covid-19 pandemic, one of the authors of this article noted the fundamental changes in the mobile lifestyle in terms of employment in the context of the increasingly huge role of new technologies, which significantly change traditional ideas about mobility. In 2014, the Institute of Social Research of Daugavpils University carried out a research project "Mobility in the Lifestyle of Today's Youth" (Menshikov 2014). The 


\section{ENTREPRENEURSHIP AND SUSTAINABILITY ISSUES}

ISSN 2345-0282 (online) http://jssidoi.org/jesi/

2021 Volume 9 Number 1 (September)

http://doi.org/10.9770/jesi.2021.9.1(36)

data of a sociological survey in Daugavpils ( $n=355$ people) made it possible to assert that for the youth of the city in the conditions of the formation of an e-society, the access to a mobile lifestyle is expanding. It turned out that by the level of mobility our respondents were distributed as follows: low - 57.8\%, medium - 32.1\% and high $10.1 \%$. In terms of employment, the largest share of young people with a high level of mobility is among students $(14.9 \%)$ and employees of private enterprises (14.1\%). For comparison: the number among schoolchildren was just $6.3 \%$.

The mobile lifestyle is a relatively little studied phenomenon, although the development of information and communication technologies significantly changes almost all manifestations of our life. Mobility, network capital, social and humanitarian technologies are becoming an increasingly essential prerequisite for successful employment. The purpose of the previously published articles was to analyse the results of a sociological project, where the object of the research was the youth of Latvia and Belarus, in order to determine, in the paradigm of mobility, the general and special perception of the youth of two countries with different economic systems of the problem of a mobile lifestyle in terms of employment (Menshikov et al. 2017a; Menshikov et al. 2017).

The following objectives of the research were among the main ones: to identify the most significant characteristics of the category of "mobile lifestyle" in the perception of young people in two countries with different economic systems (liberal in Latvia, transitional with a high share of state regulation in Belarus), to determine the most essential factors contributing to the implementation of a mobile lifestyle, the establishment of self-assessments of mobility in various types of activities, especially economic ones, the presence of experience of distance employment, the lack of labour skills, including working in the online space. Based on youth selfassessments of their mobility in certain aspects of their lifestyle, we have identified three levels of mobility: low (no more than 2 types of activity, where respondents consider themselves mobile), medium (3-4), high (from 5 to 10 types of activity). Only 7\% of respondents both in Latvia and Belarus have a high level of mobility. The data on the share of young people with an average level of mobility (Latvia-28\%, Belarus-25\%) and a low level of mobility (Latvia-65\%, Belarus -68\%) show practically no difference.

We again see a coincidence in the three types of activities where young people of Latvia and Belarus are most mobile - communication on the Internet (Latvia - 37.4\%, Belarus - 36.2\%), recreation, hobbies, entertainment, games (Latvia - 35.5\%, Belarus - 43.3\%), learning, advanced training (Latvia - 29.9\%, Belarus - 24.8\%). The youth of our countries is least mobile again in the same types of activities: entrepreneurship, one's own business (Latvia - 9.3\%, Belarus - 6.5\%), political activity, working in non-profit state organisations (Latvia - 4.7\%, Belarus - 2.9\%), participation in the activities of religious organisations, churches (Latvia - 10.3\%, Belarus $2.0 \%)$.

At the same time, young people still underestimate network capital and computer skills. Only $3.4 \%$ of the young people surveyed noted the absence of these skills, while only $27.1 \%$ of our respondents in Latvia and $21.2 \%$ in Belarus had at least some experience of remote work. And this is despite the fact that only $1 \%$ of the young people in our countries surveyed constantly worked on the basis of distance employment. Even when looking for a job, only $17 \%$ of those who have some kind of employment have successfully used the Internet.

In recent decades, scientists from different areas of social science have paid much attention to entrepreneurship as the most important factor in the dynamic development of the economy. With this in mind, it is important to understand what entrepreneurship and its potential are (Menshikov \& Ruza 2021). Entrepreneurship is any attempt to create a new enterprise or new business, for example self-employment, the establishment of a new entrepreneurial structure or the expansion of an existing business, undertaken by an individual, a group of individuals or an existing business structure. 


\section{ENTREPRENEURSHIP AND SUSTAINABILITY ISSUES}

ISSN 2345-0282 (online) http://jssidoi.org/jesi/

2021 Volume 9 Number 1 (September)

http://doi.org/10.9770/jesi.2021.9.1(36)

The degree of entrepreneurship development depends on the formation and implementation of entrepreneurial potential. Entrepreneurial potential is a type of labour potential; however, it has specific features determined by both the nature of a certain type of entrepreneurial activity and the specific features of a particular economic system.

Entrepreneurial potential is a highly complex phenomenon based on both genetic and social factors (congenital and acquired). In the scientific literature, in the reports on scientific research, we may encounter quite a few of its individual elements. In our opinion, the following should be attributed to the individual characteristics of a potential entrepreneur:

- Entrepreneurial opportunities - confidence that there are favourable conditions for starting a business in the place of residence of an individual;

- Entrepreneurial abilities - confidence that a potential entrepreneur possesses the necessary knowledge and skills to start a business;

- Entrepreneurial intentions - focus on the entrepreneurial activity of an able-bodied person who is a latent entrepreneur and plans to open a business within the next few years;

- Mobility - a characteristic of a person's lifestyle that demonstrates a high level of activity in both real and virtual space.

In particular, some researchers of the entrepreneurial potential of young people consider high mobility, flexibility of approaches, and quick response to the development of new markets its greatest strengths (Chernicov et al. 2017).

Awareness and access to various aspects of entrepreneurship can play an important role in shaping beliefs and attitudes towards entrepreneurship. By integrating different predictors of entrepreneurial intentions into one coherent framework, policymakers can better understand the complementarities of various individual and contextual variables that influence entrepreneurial intentions (Urban \& Chantson 2019). However, authors of entrepreneurship research do not always focus on the role of mobility in the "coherent structure" of entrepreneurial intentions.

In February 2020, the researchers from the Department of Economics and the Centre of Social Research of Daugavpils University surveyed 402 students in 16 higher education institutions (including all 6 Latvian universities). The sociological questionnaire included questions that made it possible to establish the parameters of students' attitude to entrepreneurship, their real involvement in entrepreneurial activity, as well as factors both promoting and hindering the accumulation of entrepreneurial potential already in their student years. In general, Latvian students declare a rather positive attitude towards entrepreneurship, where: (1) they already have their own business $-5.8 \%$, (2) there are dreams of starting their own business some time - $65.2 \%$, (3) now and hardly ever there will be such desires in the future $-29.0 \%$.

The question "To what extent are you ready to establish your own company/start your own business? was answered in a more restrained manner with the dominant (among $40 \%$ of the respondents) answer "both agree and disagree". $34 \%$ of the surveyed students are definitely not yet ready to start their own business, and $26 \%$ already have their own business, or are almost ready to create one. Unfortunately, the issues of mobility in the entrepreneurial potential of Latvian students were only indirectly reflected in the research (primarily in the aspect of incentives and obstacles to entrepreneurial activity). 


\section{ENTREPRENEURSHIP AND SUSTAINABILITY ISSUES}

ISSN 2345-0282 (online) http://jssidoi.org/jesi/ 2021 Volume 9 Number 1 (September) http://doi.org/10.9770/jesi.2021.9.1(36)

\section{Entrepreneurial mobility of students in Latvia and Georgia under the conditions of the Covid-19 pandemic (some results of a comparative exploratory research)}

In March 2021, researchers from Daugavpils University (Latvia) and Tbilisi National University (Georgia), a year after the start of the Covid-19 pandemic, began to study the issue of increasing the entrepreneurial potential of students in the context of a protracted crisis, including their mobility in the implementation of this aspect of labour activity. So far, our joint project is limited to exploratory research. The number of respondents was 122 people at Daugavpils University (hereinafter Latvia) and 145 people at Ivane Ivane Javakhishvili Tbilisi State University and European University (Georgia). At the time of the sociological survey, $8.2 \%$ of respondents in Latvia and $16.6 \%$ in Georgia had their own business, which is largely due to the specifics of the profile of their educational programmes. In Georgia, almost all surveyed students receive education in business, management and economics (98\%), in Latvia this number was only $8.1 \%$, while $25.4 \%$ of all respondents studied the law and $24.6 \%$ - art. Previous researches on entrepreneurial potential emphasize the importance of prior acquaintance with entrepreneurship (Krueger et al. 2000; Rahman \& Day 2013; Vanevenhoven \& Liguori 2013), social assessment of entrepreneurship (Kibler et al. 2014; Linan et al. 2011), entrepreneurial and social support (Hopp \& Stephan 2012; Zanakis et al. 2012; Stephan \& Uhlaner 2010).

Table 1. Comparison of data from a sociological survey of students in Latvia and Georgia on the degree of their participation in entrepreneurship, (\%)

\begin{tabular}{|l|c|c|}
\hline \multicolumn{1}{|c|}{ Answer options } & Latvia & Georgia \\
\hline $\begin{array}{l}\text { I have an idea that I would like to commercialize (build my own business } \\
\text { and make a profit) }\end{array}$ & 59,8 & 72,9 \\
\hline I am interested in doing business & 58,2 & 74,6 \\
\hline I consider myself an entrepreneurial person & 19,7 & 28,9 \\
\hline I already run my own business & 8,2 & 16,6 \\
\hline
\end{tabular}

Source: elaborated by the authors

As the data in Table 1 show, among our students there is a fairly large distance from having an idea that they could commercialize to the presence of their own business (especially among Latvian students enrolled in programmes not directly related to business, management, economics).

Apart from usual obstacles, there are now the complexities added by the current pandemic situation. This was indicated by a relatively large share of respondents $-42.6 \%$ in Latvia and $55.2 \%$ in Georgia indicated the answer option "definitely not" to the question about the possibility of implementing their idea in the current situation of the pandemic. As can be seen from the data in Table 2, the conditions of the pandemic increase the risks of starting a business and managing a company, but the dominant factor is still one's own attitude to risk, regardless of the external situation. 


\section{ENTREPRENEURSHIP AND SUSTAINABILITY ISSUES}

ISSN 2345-0282 (online) http://jssidoi.org/jesi/ 2021 Volume 9 Number 1 (September) http://doi.org/10.9770/jesi.2021.9.1(36)

Table 2. (\%) Attitude of Latvian and Georgian students to various aspects of entrepreneurial risk (\%)

\begin{tabular}{|l|c|c|}
\hline \multicolumn{1}{|c|}{ Answer options } & Latvia & Georgia \\
\hline I can call myself a person willing to take risks & 50,0 & 56,98 \\
\hline I think owning a business is risky & 66,0 & 62,50 \\
\hline I believe that starting a business in the pandemic is very risky & 67,0 & 65,06 \\
\hline I think it's risky to manage your company in the pandemic & 62,0 & 61,14 \\
\hline
\end{tabular}

Source: elaborated by the authors

Still, the dominant fact is that most of the students surveyed give a very low assessment of their own accumulated entrepreneurial potential (to one degree or another, this was indicated by $71.3 \%$ of respondents in Latvia and $63.5 \%$ in Georgia). The most important gap in the accumulation of entrepreneurial potential here the willingness to take risks (average scores on a scale, where 1 - absolutely agree, 7 - absolutely disagree in Latvia - 4.51, in Georgia - 5.14).

As may be seen from the students' answers, they unambiguously attribute risk to an obstacle to starting their own business, when higher education does not form a broader and positively coloured view of the phenomenon of risk. Apparently, neither in academic affairs, nor in research work, at meetings with successful entrepreneurs, our students receive knowledge and beliefs about the positive role of risk, about such functions of risk as protective, analytical, innovative, regulatory one (Economic 2021). When starting any new business, it is necessary to assess not only risks, but also chances. Lectures, conversations and discussions with students should be devoted to both risks and chances - both forms of actualizing the results of decisions and actions taken in an uncertain and unpredictable future. In this case, risks are the events that are unfavourable for the subject, while chances are favourable ones. At the same time, it is important to show young people that in order to make rationally grounded decisions, it is necessary to predict and evaluate both risks and chances, since when setting goals and making decisions, a person expects first of all to achieve success, that is, chances, rather than failure, that is risks.

Table 3. Distribution of answers to the question: "How did the pandemic affect your business?", (\%)

\begin{tabular}{|c|c|c|c|c|}
\hline Answer options & \multicolumn{2}{|c|}{$\begin{array}{c}\text { Latvia } \\
\text { entire array/ having their own business }\end{array}$} & \multicolumn{2}{|c|}{$\begin{array}{c}\text { Georgia } \\
\text { entire array/ having their own business }\end{array}$} \\
\hline Hasn't influenced in any way & 59,0 & 30,0 & 51,7 & 13,6 \\
\hline There is less work & 8,2 & 20,0 & 42,1 & 86,4 \\
\hline There is more work & 4,9 & 20,0 & 5,0 & 0,0 \\
\hline I am thinking about closing my business & 2,5 & 20,0 & 1,2 & 0,0 \\
\hline Other & 25,4 & 10,0 & 0,0 & 0,0 \\
\hline
\end{tabular}

\section{Source: elaborated by the authors}

Young people should be aware that mobility itself is virtually a risk. "At the same time, mobility is associated with risks," a British sociologist John Urry says in his book "Mobilities". The modern mobile world appears to be characterized by new dire threats and restrictions imposed on people, places and natural environments, as well as new opportunities to lead risky mobile lives" (Urry 2012). From a global perspective, the Covid-19 pandemic has significantly increased the uncertainty of the future for the economy and social sphere (Bedianashvili 2021), which gives the factor of mobility an additional special significance. 
ENTREPRENEURSHIP AND SUSTAINABILITY ISSUES

ISSN 2345-0282 (online) http://jssidoi.org/jesi/

2021 Volume 9 Number 1 (September)

http://doi.org/10.9770/jesi.2021.9.1(36)

Table 4. Evaluation of the role of distance learning in the development of entrepreneurial potential among students, \%

\begin{tabular}{|l|c|c|}
\hline \multicolumn{1}{|c|}{ Answer options } & Latvia & Georgia \\
\hline $\begin{array}{l}\text { Yes, it contributes, since the distance learning system allows you to discover } \\
\text { the whole spectrum of academic knowledge }\end{array}$ & 7,4 & 12,4 \\
\hline Rather yes than no, as an effective use of ICTs has increased & 23,0 & 23,4 \\
\hline $\begin{array}{l}\text { No, since the opportunity to apply one's knowledge in practice has } \\
\text { decreased }\end{array}$ & 46,7 & 37,9 \\
\hline $\begin{array}{l}\text { Rather no than yes, since the technical infrastructure of the educational } \\
\text { process is insufficient }\end{array}$ & 20,5 & 18,6 \\
\hline Other & 2,5 & 7,3 \\
\hline
\end{tabular}

Source: elaborated by the authors

Considering the phenomenon of mobility in the field of entrepreneurial activity, one should take into account that in modern conditions of globalisation, entrepreneurial activity itself largely depends on many factors, including technological, socio-economic, cultural (Bedianashvili 2018). The pandemic clearly revealed these features, which was confirmed in the process of analysing the survey results.

The data in Table 4 demonstrate that distance learning, which has become common under the conditions of the Covid-19 pandemic, was assessed rather positively only by about a third of our students in terms of developing their entrepreneurial potential, especially due to the effective use of information and communication technology (ICT). At the same time, there is also a fairly noticeable group of students (7.4\% in Latvia and $12.4 \%$ in Georgia), who highly appreciated the opportunity to independently discover a wider range of academic knowledge, which promotes entrepreneurial potential and contributes to the opening of one's own business. However, the dominant of the attitude towards distance learning is rather its negative assessment in terms of the development of entrepreneurial potential - self-isolation and communication in the online format reduce the opportunity to apply one's knowledge in practice (which turned out to be especially important for Latvian students studying in the programmes not directly related to business, management, economics).

The relatively low assessment of distance learning in terms of the formation and implementation of entrepreneurial potential, the expansion of mobility, especially in the online format, does not confirm our hypothesis about the advanced development of the generation born with the "mouse" of the virtual space in comparison with older generations. For example, in Latvia "digital people", "zoomers" make up about 300 thousand representatives of generation Z, born from 1998 to 2013, and to whom the overwhelming majority of our current students can be attributed.

Our research shows that the "digital divide" is not a problem for only older generations, as J. Van Dijk demonstrates in detail in his 2 monographs. The digital divide is one of the elements (and at the same time factors) of social inequality, hence, the general model of social inequality can be represented as follows: categorical inequalities, including personal ones (age, gender, ethnicity, level of intellectual development, personal features, health status) and positional ones (profession, education, marital status, social status, region of residence), affect the unequal distribution of resources; - unequal distribution of resources affects unequal access to digital technologies; - unequal access to digital technologies also depends on the specifics of these technologies; - a consequence of unequal access to digital technologies is a different level of participation of citizens in public life; - unequal participation in the life of society affects the strengthening of categorical inequalities and causes unequal distribution of resources. Thus, J. Van Dijk concludes that the digital divide is a real social problem of modern society, since it leads to a slowdown in economic growth and innovative 


\section{ENTREPRENEURSHIP AND SUSTAINABILITY ISSUES}

ISSN 2345-0282 (online) http://jssidoi.org/jesi/ 2021 Volume 9 Number 1 (September) http://doi.org/10.9770/jesi.2021.9.1(36)

development, increased inequality and exclusion, poses a serious threat to public safety due to the lack of control over those who have limited access and use of digital technologies.

At the end of the 20th century, there emerged works demonstrating that inclusion in social relations, belonging to a network, and the ability to use modern technologies are of fundamental importance for modern societies. J. Van Dijk considers four forms of access: motivation to the use of digital technologies, material access (having access to a device, to the Internet), access to digital skills and access to opportunities for using digital technologies (Dijk 2005). It seems that the combination of these forms of access to digital technologies could have reflected the complex and multidimensional nature of the problem of the digital divide. However, later it became obvious that to adequately describe the state of the digital divide, it is not enough to determine the form of access and its level. It is much more important to understand how this access relates to certain user strategies and practices.

In his new work, J. Van Dijk preserves the theoretical framework. However, his scheme now includes four sequential stages of not only access but also the use of digital media: motivation, physical access, digital skills, and application opportunities. The author considers "access" as the first step, the basis for studying the digital divide. The main attention should be paid to the concept of "usage". For this reason, the concept of the digital divide of the first level has been continued in the study of the digital divide of the second and third levels. In fact, the sociologist reproduces his own previously proposed concept of access demonstrating the possibilities of its application to studying the subject at all three levels. Unfortunately, J. Van Dijk implements his detailed analysis of the problems of the digital divide only in the paradigm of social stratification, without delving into the theory and reality of a mobile society and mobile lifestyles, existing digital accelerators and obstacles.

Table 5. What area will your company operate in, taking into account the conditions of the pandemic? Choose one most appropriate option, $(\%)$

\begin{tabular}{|l|r|r|}
\hline \multicolumn{1}{|c|}{ Answer options } & \multicolumn{1}{c|}{ Latvia } & \multicolumn{1}{c|}{ Georgia } \\
\hline Information technology and communications & 10,7 & 16,6 \\
\hline Trade (wholesale/retail) & 29,0 \\
\hline Consulting (law, taxes, management, personnel management) & 4,1 \\
\hline Advertising / Marketing / Design & 3,3 & 13,1 \\
\hline Education & 3,3 \\
\hline Tourism & 19,7 & 11,5 \\
\hline Catering & 4,1 & 2,8 \\
\hline Health care & 8,3 \\
\hline Other services (including finance, insurance, etc.) & 8,8 \\
\hline Architecture & 4,9 \\
\hline Construction and industry & 4,1 & \\
\hline Other & 4,8 \\
\hline & 0,7 \\
\hline
\end{tabular}

Given the specificity of the difficulties encountered during the Covid-19 pandemic and the current uncertainty in terms of full range of risks, it is not surprising that students are seriously thinking about the possible consequences for their business and what area their company will operate in, given the conditions of the pandemic. Companies are at different stages on their road to recovering from the pandemic, and the consequences of COVID-19 may vary by geographic region and economic sector. 


\section{ENTREPRENEURSHIP AND SUSTAINABILITY ISSUES}

ISSN 2345-0282 (online) http://jssidoi.org/jesi/

2021 Volume 9 Number 1 (September)

http://doi.org/10.9770/jesi.2021.9.1(36)

Students are more likely to be interested in entrepreneurship when they think it will lead to the desired results, it will gain the approval of others (Mmakgabo 2014). The decision to start an entrepreneurial activity is to a greater extent determined by the motivation of opportunity, rather than the motivation of necessity (Herrington \& Kew 2017; Maque 2017). The data in Table 5 show that students from Latvia in the pandemic would rather plan their business in such areas as advertising/marketing/design (19.7\%), trade (wholesale/retail) (12.3\%), education (11.5\%). Students from Georgia believe that opening their own business with the least consequences of COVID19 will be in such areas as trade (wholesale/retail) (29.0\%), information technology and communications (16.60\%), advertising/marketing/design (13.1\%). As may be seen from the students' responses, in the context of the protracted COVID-19 pandemic, the most preferable areas of work are those where distance employment is more common.

\section{Conclusions, proposals and discussion points}

The multifaceted and global crisis caused by the spread of COVID-19 in general negatively affected the entrepreneurial potential of students of universities in Latvia and Georgia, where exploratory research was carried out to determine the impact of distance learning and the circumstances of remote communication with teachers, fellow students, real and potential business partners on the implementation of existing business ideas. In addition to the existing obstacles recorded in the pre-crisis period, the complexity of the current situation of the pandemic is being added. This was indicated in the responses of relatively large shares of respondents in Latvia and Georgia. As follows from the data of the sociological survey, the conditions of the pandemic increase the risks of starting a business and managing a company, but the dominant factor is still one's own attitude to risk, regardless of the external situation. Our hypothesis that distance learning significantly contributes to an increase in student mobility, including in the field of virtual space and remote entrepreneurship, has not been confirmed. The "digital divide" takes place not only regarding the older generations, but also among student youth. Only about one in four of our respondents in Latvia and Georgia said that distance learning increased the efficiency of using information and communication technologies. Universities and non-governmental organisations supporting entrepreneurship are facing the difficult task of helping students to use ICT in business tasks, in increasing entrepreneurial mobility - the most important aspect of entrepreneurial potential. Digitization should become the cornerstone of enhancing student entrepreneurial mobility, thereby supporting the creation and recovery of small and medium-sized enterprises.

The sociological survey at the universities of Latvia and Georgia showed that the overwhelming majority of students want to acquire entrepreneurial competences during their studies, to gain the required minimum of entrepreneurial culture in practice. At the moment, the development of entrepreneurship in the field of creation and use of ICT, medicine, education, as well as training managers in corporate entrepreneurship in order to promote promising national technologies is topical.

We believe that the administration of universities should show a greater interest in teaching entrepreneurship, elaborating and developing educational programmes on entrepreneurship at various levels - from Bachelor's to Doctoral studies, satisfying the growing needs of their students for increasing their entrepreneurial potential and entrepreneurial mobility. It is important to develop such a direction at universities as "start-up as a diploma", as well as to introduce programmes on teaching entrepreneurship as additional education.

We assume that the House of Europe programme funded by the European Union and created to support professional and creative exchange between young people in the EU countries, deserves getting support and expansion. The programme focuses on culture and the creative sector, education, medicine, social entrepreneurship, media. For example, a mobility grant is a chance to take part in professional events in the EU countries at the expense of the programme (European 2021). 


\section{ENTREPRENEURSHIP AND SUSTAINABILITY ISSUES}

ISSN 2345-0282 (online) http://jssidoi.org/jesi/ 2021 Volume 9 Number 1 (September) http://doi.org/10.9770/jesi.2021.9.1(36)

The novelty of the research findings is that for the first time the impact of the COVID-19 crisis in the life of universities in Latvia and Georgia, primarily of the massive transition to distance learning, on the state of the entrepreneurial potential of students, especially in terms of their entrepreneurial mobility, has been clarified.

The materials, findings and conclusions of the research can be used by research organisations, government bodies, institutions of higher education, student organisations. Our research can encourage entrepreneurial scientists and strategists to realise that the scope of the concept of entrepreneurial mobility is much wider than previously estimated, opening up new interesting opportunities for theoretical and methodological development in this area.

\section{References}

Chernicov, A.E., Artamanova, J.S., Ionova, A.V. (2017). Issledovanie urovnya predprinimatel'skogo potenciala studentov vuzov v usloviyakh strategii razvitiya malogo biznesa v Rossii. [Research of the level of entrepreneurial potential of university students in the context of small business development strategy in Russia]. Retrieved April 1, 2021, from https://www.fundamentalresearch.ru/ru/article/view?id=41886

Bienkowska, D., Klofsten, M. (2012). Creating entrepreneurial networks: Academic entrepreneurship, mobility and collaboration during $\mathrm{PhD} \quad$ education, $\quad$ 64(2), 207-222. $\quad$ Retrieved April $\quad 1, \quad$ from https://www.researchgate.net/publication/257568267_Creating_entrepreneurial_networks_Academic_entrepreneurship_mobility_and_colla boration_during_PhD_education

Bednarska-Wnuk, I. (2019). Entrepreneurial Mobility-Concept, Dimensions, Meaning. Organization and Management, 4 / (187), pp.43-53. Retrieved April 1, 2021, from https://ssl-kolegia.sgh.waw.pl/pl/KZiF/czasopisma/oik/numery/Documents/2019-4-187/bednarskawnuk_entrepreneurial_mobility_concept_dimensions_meaning.pdf

Bedianashvili, G. (2021). Macroeconomic and Cultural Determinants of the COVID-19 Pandemic Crisis. Bulletin of the Georgian National Academy of Sciences, 15(2), 191-197. http://science.org.ge/bnas/vol-15-2.html

Bedianashvili, G. (2018). Knowledge Economy, Entrepreneurial Activity and Culture Factor in Modern Conditions of Globalization: Challenges for Georgia. Globalization and Business, 5, 32-37. https://doi.org/10.35945/gb.2018.05.004

Dijk, J. (2005). The Deepening Divide: Inequality in the Information Society. Thousand Oaks, CA: Sage, p. 240.

Economic and Finance. Uchebnye materialy. [Educational materials]. Retrieved February 12, 2021, from http://finans-study.ru/ponyatie-i$\underline{\text { funkcii-riska.html }}$

European Union and the Consortium partners. (2021). House of Europe knowledge library. Retrieved August 16, 2021, from https://www.houseofeurope.org.ua/en?fbclid=IwAR16MLoeUQEf7rRTY19wQ2S_Aw-_Q_Hn8vQttUazDiYco7fWNwDsRuU151s

Guterrish, A. (2021). Krizis COVID-19-vozmozhnost' pereosmyslit' voprosy chelovecheskoy mobil'nosti. [COVID-19 crisis - an opportunity to rethink human mobility issues]. Retrieved April 1, 2021, from https://www.un.org/pt/node/74528

Herrington, M., Kew, P. (2017). Global Entrepreneurship Monitor: Global Report 2016/17, p.1-179

Hopp, C., Stephan, U. (2012). The influence of socio-cultural environments on the performance of nascent entrepreneurs: Community culture, motivation, self-efficacy and start-up success. Entrepreneurship \& Regional Development: An International Journal, 24(9-10), 917-945. https://doi.org/10.1080/08985626.2012.742326

Kibler, E., Kautonen, T., Fink, M. (2014). Regional social legitimacy of entrepreneurship: Implications for entrepreneurial intention and start-up behaviour. Regional Studies, 995-1015. https://doi.org/10.1080/00343404.2013.851373

Krueger, N. F., Reilly, M. D., Carsrud, A. L. (2000). Competing models of entrepreneurial intentions. Journal of Business Venturing, 15, 411-432. https://doi.org/10.1016/S0883-9026(98)00033-0 


\section{ENTREPRENEURSHIP AND SUSTAINABILITY ISSUES}

ISSN 2345-0282 (online) http://jssidoi.org/jesi/ 2021 Volume 9 Number 1 (September) http://doi.org/10.9770/jesi.2021.9.1(36)

Lundmark, E., Waern, A. (2008). What is mobile in entrepreneurship? Heling Working Press 08/9. Linkoping: Linkoping University, p. 42. Retrieved January 8, 2021, from https://www.diva-portal.org/smash/get/diva2:757772/FULLTEXT01.pdf

Linan, F., Urbano, D., Guerrero, M. (2011). Regional variations in entrepreneurial cognitions: Start-up intentions of university students in Spain. Entrepreneurship and Regional Development, 23(3-4), 187-215. https://doi.org/10.1080/08985620903233929

Maque, M.R., Kabir, M.Z., Rahman, M.M., Chowdhury, S.P., Islam, S. (2017). Entrepreneurial Intentions: A Study on Students from Countryside University, Asian Economic and Financial Review. Asian Economic and Social Society, 7(10), 972-980. https://doi.org/10.18488/journal.aefr.2017.710.972.980

McFarlane, C. (2012). The Entrepreneurial Slum: Civil Society, Mobility and the Co-production of Urban Development. Urban Studies, 49(13), 2795-2816.

Mmakgabo, J. (2014). Entrepreneurial Intentions and Entrepreneurial Motivation of South African Rural University Students. Journal of Economics and Behavioral Studies, 6(9), 709-726. https://doi.org/10.22610/JEBS.V6I9.531

Menshikov, V. (2014). Mobility in the lifestyle of today's youth. Philosophy.Sociology, 25(4) Vilnius, Lithuanian Academy of Science, 247-253.

Menshikov V., Lavrinenko, O., Vankevich, E.(2017a). Mobile Lifestyle of Latvian and Belarusian Youth in the Aspect of Employment. Filosofija.Sociologija, 28(4), 236-245.

Menshikov, V., Lavrinenko, O., Vankevich, E. (2017). Mobile Lifestyle of Youth in the Aspect of Employment. Ekonomichnyi visnyk universytetu, 34(1), 188-197. Retrieved April 1, 2021, from http://nbuv.gov.ua/UJRN/ecvu_2017_34\%281\%29_23

Menshikov, V., Ruza, O. (2021). Entrepreneurial Potential of Students. Ekonomichnyi visnyk universytetu, 49, 70-80. https://doi.org/10.31470/2306-546X-2021-49-70-80

Rahman, H. \& Day, J. (2013). The relationship between role models and student entrepreneurial motivation. Journal of Entrepreneurship Education, 17(2). Retrieved May 25, 2021, from http://sbaer.uca.edu/research/icsb/2012/Rahman\%20142.pdf

Storper, M., Anthony, J. (2004). Venable. Buzz: Face-To-Face Contact and the Urban Economy. Journal of Economic Geography, 4(4), 351-3704. Retrieved Juny 1, 2021, from https://doi.org/10.1093/jnlecg/lbh027

SCOPUS1. (2021). Chislo dokumentov po godam, kotorye soderzhat slova «mobil'nost'» v nazvanii, annotatsii ili klyuchevykh slovakh v baze dannykh Scopuss c 2015 po 2020 god. [Number of documents by year that contain the words "mobility" in the title, abstract or keywords in the Scopus database from 2015 to 2020]. Retrieved April 21, 2021, from https://www.scopus.com/results/results.uri?sid=cfb5f1d8365d4c7b9b53855b302e8dbe\&src=s\&sot=b\&sdt=b\&origin=searchbasic\&rr=\&sl= 23\&s=TITLE-ABS-KEY(Mobility)\&searchterm1=Mobility\&searchTerms=\&connectors=\&field1=TITLE_ABS_KEY\&fields=

SCOPUS2. (2021). Chislo dokumentov po otrosljam nauki, kotorye soderzhat slova «mobil'nost'» v nazvanii, annotatsii ili klyuchevykh slovakh v baze dannykh Scopuss c 2015 po 2020 god. [The number of documents by branch of science that contain the words "mobility" in the title, abstract or keywords in the Scopus database from 2015 to 2021]. Retrieved April 21, 2021, from

https://www.scopus.com/results/results.uri?sid=cfb5f1d8365d4c7b9b53855b302e8dbe\&src=s\&sot=b\&sdt=b\&origin=searchbasic \& rr $=\&$ sl $=$

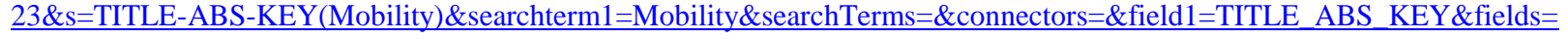

SCOPUS3. (2021). Chislo dokumentov po stranam, kotorye soderzhat slova «mobil'nost'» v nazvanii, annotatsii ili klyuchevykh slovakh v baze dannykh Scopuss 2015 po 2021 god. [The number of documents by country that contain the words "mobility" in the title, abstract, or keywords in the Scopus database from 2015 to 2021]. Retrieved April 21, 2021, from

https://www.scopus.com/results/results.uri?sid=cfb5f1d8365d4c7b9b53855b302e8dbe\&src=s\&sot=b\&sdt=b\&origin=searchbasic \& $\mathrm{rr}=\&$ sl $=$ $\underline{23 \& s=T I T L E-A B S-K E Y}($ Mobility)\&searchterm1=Mobility\&searchTerms=\&connectors=\&field1=TITLE_ABS_KEY\&fields=

Stephan, U., Uhlaner, L.M. (2010). Performance-based vs socially supportive culture: A cross-national study of descriptive norms and entrepreneurship. Journal of International Business Studies, 41, 1347-1364. https://doi.org/10.1057/jibs.2010.14

Urry, J. (2002). Mobility and proximity. Sociology, 36 (2), pp. 255-274.

Urry, J. (2012). Mobility. Per. s angl. A.V. Lazareva. M.: Praksis. [Translate from English A. V. Lazareva. M.: Praxis], p. 576.

Urry, J. (2013). Mobil'nost' i blizost'. [Mobility and proximity]. Sociological research, p. 3-14. 


\section{ENTREPRENEURSHIP AND SUSTAINABILITY ISSUES}

ISSN 2345-0282 (online) http://jssidoi.org/jesi/ 2021 Volume 9 Number 1 (September)

http://doi.org/10.9770/jesi.2021.9.1(36)

United Nations Economic Commission for Europe. (2020). Sustainable Development GOALS. UNECE launches handbook on sustainable urban mobility and spatial planning to help steer cities' green recovery. Retrieved April 1, 2021, from https://unece.org/ru/press/eek-oonvypuskaet-rukovodstvo-po-ustoychivoy-gorodskoy-mobilnosti-i-prostranstvennomu

Urban, B., Chantson, J. (2019). Academic entrepreneurship in South Africa: testing for entrepreneurial intentions. The Journal of Technology Transfer. Retrieved April 1, 2021, from https://www.semanticscholar.org/paper/Academic-entrepreneurship-in-SouthAfrica\%3A-testing-Urban-Chantson/aefc316a2a9fbc036bae76f339064fa8cc2977a2\#related-papers, https://doi.org/10.1007/S10961-0179639-Z

Vanevenhoven, J., Liguori, E. (2013). The impact of entrepreneurship education: Introducing the entrepreneurship education project. Journal of Small Business Management, 51(30), 315-328. https://doi.org/10.1111/jsbm.12026

Zanakis, S. H., Renko, M., Bullough, A. (2012). Nascent entrepreneurs and the transition to entrepreneurship: Why do people start new businesses? Journal of Developmental Entrepreneurship, 17(1), 1-25. https://doi.org/10.1142/S108494671250001X

Zahra, A., Wright, M. (2011). Entrepreneurship's Next Act. Academy of Management Perspectives, 25(4), 67-83.

\section{Acknowledgement}

The article has been elaborated within research project No.14-95/2021/17 of Daugavpils University "The potential of student entrepreneurship and its promotion in Latvia, Ukraine and Georgia".

Vladimir MENSHIKOV is Dr.sc.soc., Professor at Daugavpils University. His research interests include sociology of security; regional development; capital theory. He is an Expert of the Latvian Council of Science in the fields of economics and sociology. He is a head of the Centre of Social Research of Daugavpils University, Latvia.

ORCID ID: https://orcid.org/0000-0001-9988-8588

Givi BEDIANASHVILI is Dr. Sc. oec., Professor, Director of the Institute for the Research of Economic and Social Problems of Globalization at European University. Chief editor of journal "Globalization and Business", Professor (associate) at Ivane Javakhishvili Tbilisi State University (Georgia). His research interests include green economy and sustainable development, macroeconomics, entrepreneurial activities, systems research, digital economy and business.

ORCID ID: https://orcid.org/0000-0003-4521-737X

Irēna KOKINA, Prof. Dr. psych., rector of Daugavpils University, Latvia. She is an Expert of the Latvian Council of Science in the fields of Psychology and of Economics and Entrepreneurship. Her research interests include sustainable development, issies of psychology and management.

ORCID ID: https://orcid.org/0000-0001-6778-0783

Oksana RUZA is Dr.oec., Docent, Researcher at the Institute of Humanities and Social Sciences of Daugavpils University (Latvia). She is an Expert of the Latvian Council of Science in the fields of economics. Her research interests include regional economics, industrial economics, finances.

ORCID ID: https://orcid.org/0000-0002-6194-3841 
ENTREPRENEURSHIP AND SUSTAINABILITY ISSUES

ISSN 2345-0282 (online) http://jssidoi.org/jesi/

2021 Volume 9 Number 1 (September)

http://doi.org/10.9770/jesi.2021.9.1(36)

Make your research more visible, join the Twitter account of ENTREPRENEURSHIP AND SUSTAINABILITY ISSUES: @Entrepr69728810

Copyright (C) 2021 by author(s) and VsI Entrepreneurship and Sustainability Center

This work is licensed under the Creative Commons Attribution International License (CC BY).

http://creativecommons.org/licenses/by/4.0/

(c) †) Open Access 